\title{
Effect Of Flexural Strength Of Denture Base Resin Reinforced By Three Different Nanoparticle Materials (In Vitro Study)
}

\author{
Noha Helmy, Mohamed Aboshama, Mahmoud Ammar*1
}

Codex : 04/2021/04

Aadj@azhar.edu.eg

\section{KEYWORDS}

Reinforced of denture base acrylic resin, flexural strength, Zirconium oxide, Aluminum oxide, Titanium oxide nanoparticles.

\section{ABSTRACT}

Aim: estimate flexural strength of strengthened denture base resin by different concentrations of Zirconium oxide nanoparticles (Zro2 Nps), Aluminum oxide nanoparticles (Al2o3 Nps) and Titanium oxide nanoparticles (Tio2 Nps). Subjects and methods: fifty sample were got ready to experimentation of flexural strength together with dimensions 65 length $\times 10$ width $\times 2.5 \mathrm{~mm}$ thickness and then these samples were split into 4 series (A, B, C, D) and these groups then partitioned to 3 sub collections $(1,2$, and 3$)$ of 5 specimens for each group according to the ratio of Zro2Nps, Al2o3 Nps and Tio 2 Nps which were $(1 \%, 2 \%$ and $3 \%)$ for each type of nanoparticles that were added to heat-cured Poly methyl methacrylate (PMMA). Results: Regardless to metal oxide type, totally the highest mean value was recorded for control group (77.96 MPa). The difference between groups was statistically significant as indicated by ANOVA test $(\mathrm{p}=<0.0001<0.05)$ for flexural strength. Conclusions: It was found that there is slight decreasing in transverse strength of PMMA for all concentrations added of Zro2Nps, A12o3 Nps and Tio2 Nps when compared to control group.

\section{INTRODUCTION}

Poly methyl methacrylate (PMMA) is acrylic resin usually choose as a denture base substance because its minimum price, perfect adaptability, facility of implementation, and usage in complete denture, overdenture and orthodontic devices. ${ }^{(1)}$

Clinically progressing the physical and mechanical characteristic of PMMA may be beneficial in marks which masticatory forces are comparatively high, such as distal extensions counteract naturalistic dentition, single complete dentures, overlay denture and hybrid prothesis.$^{(2)}$ This demand is highly serious, particularly in old patients, to remove conditions such as denture fracture. Furthermore, improving the mechanical and physical features of PMMA may assist old patients, who may be damage or have obstacle adjusting to a newly prosthesis, raise the durability of their denture. ${ }^{(3)}$ 
Different techniques had been applied to raise the intensity of acrylic denture base and minimize the danger of prosthesis break.$^{(4)}$

In dental medicine, alchemical manufacture study these days are centering in adding of nanoparticles like as titanium dioxide ( $\mathrm{TiO} 2)$, silicon dioxide (Sio2), aluminum oxide(Al2o3) and zirconium dioxide ( $\mathrm{ZrO} 2)$, into an acrylic resins to manufacture modern matters which have the similar mechanical characteristics for the nano-oxide particles, however with the elasticity of the polymer matrix. ${ }^{(5)}$

To produce denture resin matter with enhance intensity a ceramic filler such as $\mathrm{ZrO} 2$ will be combined in acrylic polymer of PMMA. It is a compatible matter which had peak - break opposition and added up to acrylic resin and another dental polymers, restorative and ceramic substances to enhance the fracture stiffness. ${ }^{(6)}$

TiO2 NPs had graded their road in dental medicine depend on its premium conveniently characteristics and were used to a diversity of resin and polymers to progress their features. ${ }^{(7)}$

\section{MATERIALS AND METHODS}

In overall, fifty samples were made for flexural strength experiment, with measurement 65 longitude $\times 10$ width $\times 2.5 \mathrm{~mm}$ thickness, were split into 4 groups (A, B, C, D) and these groups further subdivided into three subgroups $(1,2$, and 3$)$ of 5 specimens for each group (Fig. 1) according to the ratio of Zro2Nps, Al2o3 Nps and Tio2 Nps that were added to heat-cured

\section{PMMA as follows:}

I- Group A: control (PMMA without additive),

II- Group B: group B1(PMMA with $1 \%$ Zro2 Nps), group B2(PMMA with 2\%Zro2 Nps), group B3(PMMA with 3\%Zro2 Nps).
III- Group C: groupC1(PMMA with 1\% Al2o3 Nps), groupC2(PMMA with 2\% Al2o3 Nps), groupC3(PMMA with 3\% Al2o3 Nps).

IV- Group D: group D1(PMMA with 1\%Tio2 Nps), group D2(PMMA with 2\% Tio2 Nps), group D3(PMMA with 3\% Tio2 Nps).

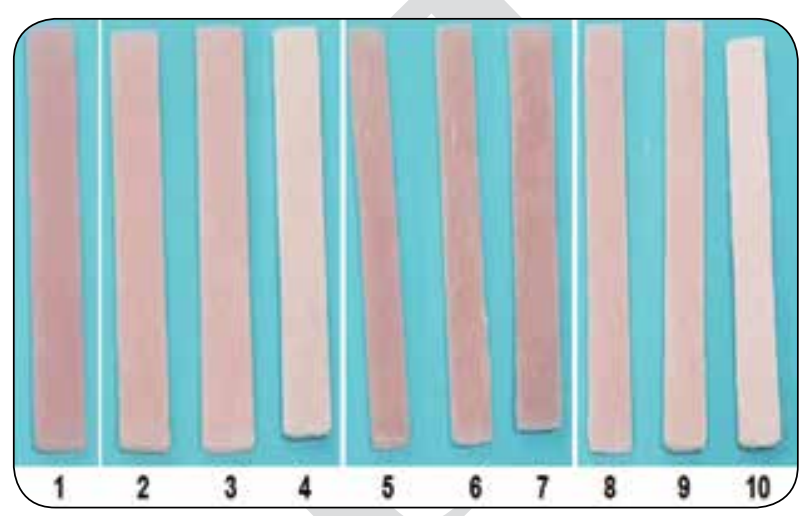

Fig. (1) (1) control, (2) $1 \%$ Zro2 Nps, (3) $2 \%$ Zro2 Nps, (4) $3 \% \mathrm{Zro} 2 \mathrm{Nps},(5) 1 \% \mathrm{Al} 2 \mathrm{o} 3 \mathrm{Nps}$, (6) $2 \% \mathrm{Al} 2 \mathrm{o} 3$ Nps, (7) $3 \%$ Al2o3 Nps, (8) $1 \%$ Tio2 Nps, (9) $2 \%$ Tio2 Nps, (10) $3 \%$ Tio2 Nps.

These concentrations were combined into heat-cure acrylic resin and cured according to manufacturer's instructions (2.5:1 Powder/ monomer ratio, conventional packing method and water bath curing) to fabricate test specimens of PMMA.

All samples were singly mounted on a computercontrolled material testing machine (Fig.2).

Every sample placed on the bending fixture which constructs of 2 equivalent upholding (50) $\mathrm{mm}$ apart, the full scale was $50 \mathrm{~kg}$, and the loading was enforced with towards top rapidity of one millimeter per minute by a bar positioned medianally among supports making deflection until fracture occur, the ultimate loading prior break was gauged, the outcomes registered through the 3 dot bending test.

All information was statistically resolved through One-way ANOVA, Tukey post hoc tests. 


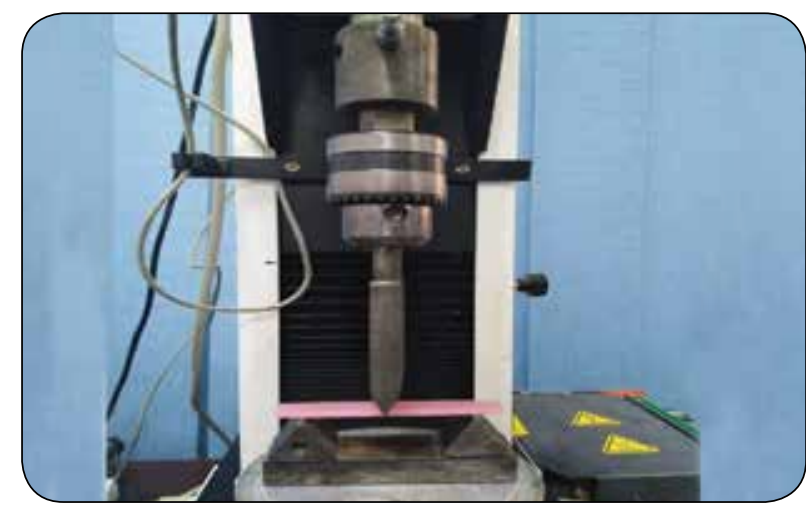

Fig. (2) Mounting the sample on testing machine (Instron)

\section{RESULTS}

It is found that the highest mean value was recorded for control group $77.96 \mathrm{MPa}$ regarding flexural strength as shown in table (1). The difference between groups was statistically significant as indicated by ANOVA test $(\mathrm{p}=<0.0001<0.05)$ for flexural strength as shown in (Fig.3).

Table (1) Descriptive statistics of flexure strength test results (Mean values \pm SD) for acrylic resin with/out different concentrations of metal oxides modifications

\begin{tabular}{|c|c|c|c|c|c|c|}
\hline \multirow{2}{*}{ Group } & \multirow{2}{*}{ Conc. \% } & \multirow{2}{*}{ Mean } & \multirow{2}{*}{ SD } & \multicolumn{2}{|c|}{ Range } & \multirow{2}{*}{$\frac{\text { Statistics }}{\text { Pvalue }}$} \\
\hline & & & & Min. & Max. & \\
\hline \multirow{3}{*}{$\begin{array}{l}\dot{\Xi} \\
\stackrel{\Xi}{\Xi} \\
\dot{N}\end{array}$} & $1 \%$ & $64.93^{\mathrm{b}}$ & 3.87 & 56.59 & 70.42 & \multirow{3}{*}{$<0.0001 *$} \\
\hline & $2 \%$ & $56.06^{c}$ & 5.85 & 47.43 & 62.19 & \\
\hline & $3 \%$ & $69.21^{b}$ & 9.25 & 57.56 & 92.33 & \\
\hline \multirow{3}{*}{$\begin{array}{l}\stackrel{0}{g} \\
\stackrel{\Xi}{\Xi}\end{array}$} & $1 \%$ & $57.22^{\mathrm{c}}$ & 7.29 & 42.14 & 73.89 & \multirow{3}{*}{$<0.0001^{*}$} \\
\hline & $2 \%$ & $50.57^{d}$ & 4.32 & 43.79 & 56.37 & \\
\hline & $3 \%$ & $54.94^{c}$ & 6.79 & 40.85 & 65.72 & \\
\hline \multirow{3}{*}{ 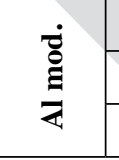 } & $1 \%$ & $66.4^{\mathrm{b}}$ & 1.96 & 63.4 & 69.54 & \multirow{3}{*}{$<0.0001^{*}$} \\
\hline & $2 \%$ & $54.22^{\mathrm{c}}$ & 2.04 & 50.57 & 56.72 & \\
\hline & $3 \%$ & $56.71^{\mathrm{c}}$ & 3.07 & 50.91 & 60.93 & \\
\hline \multicolumn{2}{|c|}{ Control } & $77.96^{\mathrm{a}}$ & 3.63 & 68.88 & 81.03 & \\
\hline Statistics & P value & \multicolumn{5}{|c|}{$<0.0001^{*}$} \\
\hline
\end{tabular}

Different letters in same column in same metal oxide modified group compared to control indicating significant $(p<0.05) \quad *$; significant $(p<0.05)$ $n$; ; non-significant $(p>0.05)$

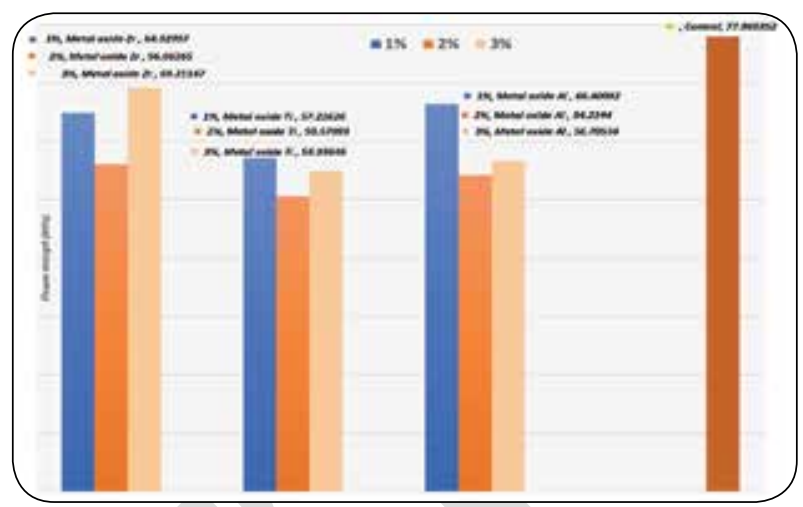

Fig. (3) Column chart showing flexure strength mean values for metal oxides modified acrylic groups compared to control group

\section{DISCUSSION}

It was found that, highest flexure was control group (Group A) 77.9Mpa.

In regard to Zro2 Nps, the transverse strength of Group B3(69.21) higher than Group B1(64.92) and Group B2(56.06), Group B3 and nearly Group B1 compatible with reference value $(65 \mathrm{Mpa})$ but Group B2 lower than reference value.

These findings of decreasing flexure strength than control group are in disagreement with Xinjing et al. ${ }^{(8)}$ and Alhareb et al.${ }^{(9)}$ research that revealed enhancement in flexural value in general.

In the current research it was discovered that, flexure strength increased with increasing Zro2 Nps but still lower than control group, this mean that Group B3 greater than Group B1. This increasing by increasing filler load may be because rise interfacial shear strength among resin matrix and the nanofiller as a outcome of forming of cross-links or supra molecular bonding which cap or mask the nanofillers which in turn hinder diffusion of crack. ${ }^{(10)}$

However, in general decreasing in flexural strength of all groups of Zro2 Nps than control group this in agreement with Gad et al. ${ }^{(11)}$ and Ergun et al. ${ }^{(12)}$ findings. One of the causes is increasing the filler content in addition to poor dispersion will results in suspending resin matrix continuity and creating defect in the material which weakens it in the outcome.(2) 
In regard to $\mathrm{Al} 2 \mathrm{o} 3 \mathrm{Nps}$, it was found that mean of flexure strength decrease with increasing A12o3 filler loading.

These results are in agreement with Fathie et al., Chehusna et al. and Zninal et al. which found that raising the quantities of the nano-Al2o3 fillers minimize the flexural strength.$^{(13)}$ this phenomenon would be clarified by the existence of agglomerates and voids, which are start factors for failure and high filler fractions led to more filler-filler interaction than filler-matrix interaction;consequently,agglomeration serve as a points of stress concentration, which may lead to inappropriate stress distribution. ${ }^{(14)}$

And for Tio2 Nps, it was found that mean of flexure strength decrease with increasing of Tio $2 \mathrm{Nps}$ concentrations. These findings are in disagreement with Kusha Thakur, Archana Nagpal and Gupta R. which found that increasing in flexure strength coincide with increase concentration of Tio2 Nps till $2.5 \%$ then decrease flexure strength.$^{(15)}$

But our results in agreement with Hamouda et al ${ }^{(16)}$ and Nazirkar et al. in were discovered the influence of affixing TiO2NP into heat cure acrylic resin notified an reverse influence on flexural strength of the definitive output. ${ }^{(17)}$ This minimizing was due to a raise in redundant $\mathrm{TiO} 2$ nanoparticles may raise the danger of dissimilar mixing among polymers output in additional monomers does not interact to polymer so that the residual monomer rises and minimize cross linking among the polymer chains. The residual monomer represents as a plasticizer since it was capable to step inside among the polymer chains which occasion the separate chains turned into more tenuous and the attraction force among molecules minimizes so that the acrylic resin turns into more flexible but brittle during the flexural strength experiment. ${ }^{(18)}$

Nazirkar et al. informed a decrease in flexural strength amounts when contrast to the classic unmodified resin. The authors explained that the reinforced TiO2NPs act as an impurity and intervenes with the polymerization process. They also stated that the TiO2NPs additives also rises the standard of residual monomer by acting as a plasticizer reducing the strength of the resin ${ }^{(7)}$

Internal prostheses synthetic with strengthen PMMA may offered a best prediction when contrast to prostheses without the adding of zirconia particles. Approaching the outcomes regarding to the characteristics of the zirconia particles, their size and concentration, the second hypothesis was partly agreeable The size of the particles were shown to have no influence on the raise in the flexural strength of PMMA, although several authors prefers the utilize of nanoparticles \{de Souza Leão, 2019, Influence of addition of zirconia on PMMA: A systematic review $\}^{(19)}$

\section{CONCLUSION}

The research be deduced that, There is decreasing in transverse strength of PMMA for all concentrations added of Zro2Nps, Al2o3 Nps and Tio2 Nps when compared to control group.

\section{REFERENCES}

1. Maji P, Choudhary RB, Majhi M. Structural, optical and dielectric properties of $\mathrm{ZrO} 2$ reinforced polymeric nanocomposite films of polymethylmethacrylate (PMMA). Optik. 2016;127(11):4848-53.

2. Asopa V, Suresh S, Khandelwal M, Sharma V, Asopa SS, Kaira LS. A comparative evaluation of properties of zirconia reinforced high impact acrylic resin with that of high impact acrylic resin. The Saudi Journal for Dental Research. 2015;6(2):146-51.

3. Komagamine Y, Kanazawa M, Sasaki Y, Sato Y, Minakuchi S. Prognoses of new complete dentures from the patient's denture assessment of existing dentures. Clinical oral investigations. 2017;21(5):1495-501.

4. Ravindranath SC, Vinayagavel K, Rupkumar P, Sriramprabhu G, Choubey A, Elavarasan S, et al. A comparative study to evaluate the mechanical properties of zirconium oxide added polymethyl methacrylate by two different methods at two different concentrations-in vitro study. Ann Int Med Dent Res. 2015;1:161-5. 
5. Alnamel HA, Mudhaffer M. The effect of Silicon di oxide Nano-Fillers reinforcement on some properties of heat cure polymethyl methacrylate denture base material. Journal of baghdad college of dentistry. 2014;26(1):32-6.

6. Fahmi MK, Ebrahim MI, Arora P. Enhancement of Mechanical Properties of Polymethylmetha-crylate Denture Base Material by Zirconium Oxide Nanofiller. World. 2019;10(2):115.

7. Bangera MK, Kotian R, Ravishankar N. Effect of titanium dioxide nanoparticle reinforcement on flexural strength of denture base resin: A systematic review and meta-analysis. Japanese Dental Science Review. 2020;56(1):68-76.

8. Zhang XJ, Zhang XY, Zhu BS, Qian C. Effect of nano $\mathrm{ZrO} 2$ on flexural strength and surface hardness of polymethylmethacrylate. Shanghai kou qiang yi xue $=$ Shanghai journal of stomatology. 2011;20(4):358-63.

9. Alhareb AO, Ahmad ZA. Effect of $\mathrm{Al} 2 \mathrm{O} 3 / \mathrm{ZrO} 2$ reinforcement on the mechanical properties of PMMA denture base. Journal of Reinforced Plastics and Composites. 2011;30(1):86-93.

10. Ahmed MA, Ebrahim MI. Effect of zirconium oxide nanofillers addition on the flexural strength, fracture toughness, and hardness of heat-polymerized acrylic resin. World journal of nano science and engineering. 2014;2014.

11. Gad MM, Rahoma A, Al-Thobity AM, ArRejaie AS. Influence of incorporation of $\mathrm{ZrO} 2$ nanoparticles on the repair strength of polymethyl methacrylate denture bases. International journal of nanomedicine. 2016;11:5633.

12. Ergun G, Sahin Z, Ataol AS. The effects of adding various ratios of zirconium oxide nanoparticles to poly (methyl methacrylate) on physical and mechanical properties. Journal of oral science. 2018;60(2):304-15.
13. Kundie F, Azhari $\mathrm{CH}$, Ahmad ZA. Effect of nano-and micro-alumina fillers on some properties of poly (methyl methacrylate) denture base composites. Journal of the Serbian Chemical Society. 2018;83(1):75-91.

14. Zare Y. Study of nanoparticles aggregation/agglomeration in polymer particulate nanocomposites by mechanical properties. Composites Part A: Applied Science and Manufacturing. 2016;84:158-64.

15. Thakur K, Nagpal A, Gupta R, Verma R, Saini R, Mahajan V. Evaluation of the Transverse Strength of the Heat Cure PMMA Resin Reinforced with Various Concentrations of Two Different Nanoparticles: An In vitro Study. Journal of Advances in Medicine and Medical Research. 2019:1-8.

16. Hamouda IM, Beyari MM. Addition of glass fibers and titanium dioxide nanoparticles to the acrylic resin denture base material: comparative study with the conventional and high impact types. Oral Health Dent Manag. 2014;13(1):107-12.

17. Nazirkar G, Bhanushali S, Singh S, Pattanaik B, Raj $\mathrm{N}$. Effect of anatase titanium dioxide nanoparticles on the flexural strength of heat cured poly methyl methacrylate resins: An in-vitro study. The Journal of Indian ProsthodonticSociety.2014;14(1):1449.

18. Tandra E, Wahyuningtyas E, Sugiatno E. The effect of nanoparticles $\mathrm{TiO} 2$ on the flexural strength of acrylic resin denture plate. Padjadjaran Journal of Dentistry. 2018;30(1):35-40.

19. de Souza Leão R, de Moraes SLD, de Luna Gomes JM, Lemos CAA, da Silva Casado BG, do Egito Vasconcelos BC, et al. Influence of addition of zirconia on PMMA: A systematic review. Materials Science and Engineering: C. 2019:110292. 
مجلة أسيوط لطب الأسنان
النشر الرسمي لكلية طب الأسنان

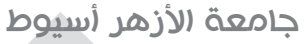

\section{تأثير قوه الانثناء لمادة الترنج المعززة بواسطة ثلاث مواد

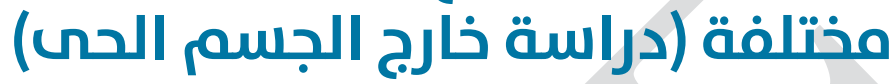

\section{نهي حلمي , محمد أبو شامة"، محمود عمار}

1. قسـم الإسـتعاضـة الصناعية المتحركة ، كلية طب الاسـنان، ( أسيوط,بنـين)، جامعـة الازهر، مصر

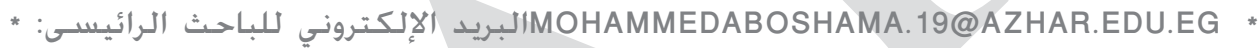

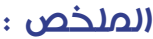

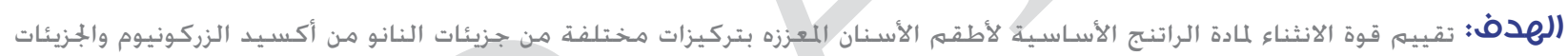
النانو من أكسيد الألومنيوم و الجزيئات النانوة من الكناء الكسيد التيتانيوم.

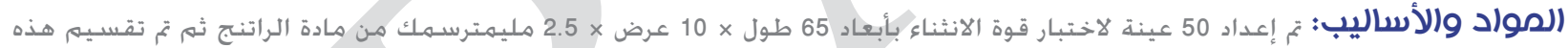

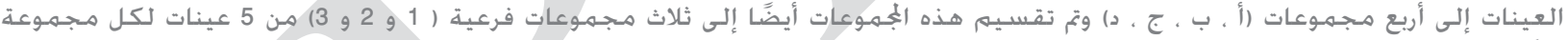

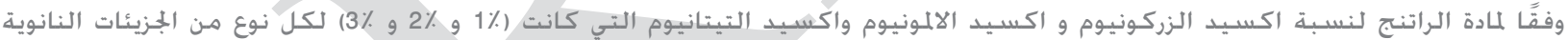

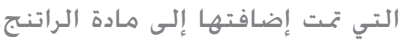

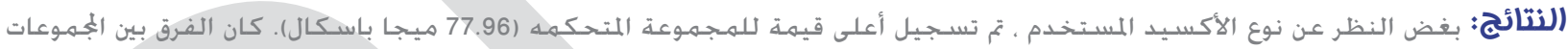

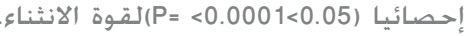

الاستنتاج: هناك انخفاض طفيف في القوة الانثناء لـمادة الراتنج لجميع التركيزات المضافة من اكسبيد الزركونبوم و اكسيد الالمونيوم

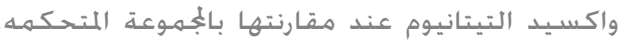

الكلمات الدفتاحية: المادة الراتنج المعززة , قوة الانثناء, الجزيئات النانو من أكسيد الزركونيوم , الجزيئات النانو من أكسيد الألومنيوم و

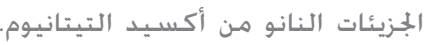

